\title{
PROBLEMATIZING LEXICO-GRAMMATICAL EQUIVALENCE IN ARABIC-ENGLISH TRANSLATION
}

\author{
Tawffeek Abdou Saeed Mohammed Al-Kenani* \\ University of the Western Cape, South Africa \\ Robert Sobukwe Rd, Bellville, Cape Town, 7535 \\ Received 30 April 2018 \\ Revised 6 February 2019; Accepted 30 May 2019
}

\begin{abstract}
This study deals with the concept of grammatical equivalence in Arabic-English translation. It investigates the problems that encounter student translators (STs) while translating grammatical constructions from Arabic into English. It is based on a parallel corpus of the translations of five groups of STs at the Department of English, Faculty of Arts, Taiz University, Yemen. The STs are doing their final year and by the time of the administration of the tasks, they had already studied 4 translation courses. The study concluded that the structural and morphological differences between Arabic and English have created various problems for the STs. Following Systemic Functional Grammar (SFG), the grammatical problems at the ideational, interpersonal, textual and logico-semantic metafunctions were identified. The study concluded that the STs encountered various problems in terms of transitivity, modality, thematic structures, logical dependency and logico-semantic relations between the clauses. Those problems have not only affected the stylistic and grammatical aspects of the target texts, but they have sometimes yielded a meaning different from the one intended by the author(s).
\end{abstract}

Keywords: Translation, equivalence, grammatical, Arabic, English, Systemic Functional Grammar (SFG), clause, student translators (STs)

\section{Introduction}

Teaching some translation modules for students pursuing a degree in English Language and Translation at a number of Yemeni universities has brought to our attention a number of problems encountered in Arabic to English translation. In fact, many studies have investigated problems involving the translation of some grammatical structures such as passivization, modality, relativization, conjunction, etc. However, most of those studies are based on a comparative/contrastive analysis of artificial decontextualized Arabic sentences and their translations and not on empirical studies that use various genres and text types.

\footnotetext{
* Tel.: 0027767291362

Email: tawffeek@gmail.com
}

This study is mainly concerned with the grammatical problems that encounter student translators (STs) while translating texts from Arabic into English. It is based on the researcher's PhD thesis (Mohammed, 2011). It is also a part of an ongoing cross-sectional empirical project that aims to investigate the problems encountered by student translators (STs), novice translators (NTs) as well as more experienced translators (Ts). In addition to elicitation tasks, which were mainly used in the researcher's $\mathrm{PhD}$ thesis, Thinking Aloud Protocols (TAPs), Translog keyboard capturing, audio recording and playback and eye-tracking are employed in the project.

Arabic and English belong to different language families. As a result, there are very significant differences between the two languages at the grammatical level. 
Morphologically, Arabic is categorized as an inflectional, derivational and templatic language (Alasmari et al., 2016). English, however, shows only some of those features (Shamsan \& Attayib, 2015). Syntactically, Arabic is a null-subject or a theme pro-drop language. Even though the subject pronouns are omitted, the meaning of a sentence can be determined from the grammatical context. Arabic also differs from English in terms of tense, aspect, grammatical gender, number, etc. Those differences in addition to the prolificacy of free word-order in Arabic are likely to pose several translation problems to the STs. In their attempt to achieve what we may call the ideal equivalence/correspondence of a grammatical form, STs are more inclined to translate a text literally and thereby they make several errors. Grammatical equivalence is sometimes hardly attainable. In what follows, we will briefly summarize the literature on the concept of equivalence in general and grammatical equivalence in particular.

\section{Grammatical Equivalence}

Equivalence is a key concept in translation studies. It has been a matter of heated discussion among philosophers, linguists, and translation theorists. Their debate has produced many dichotomies. A major contribution to the theory of equivalence came from Nida (1964) who argued that equivalence can be formal or dynamic. As he was interested in Biblical texts, he emphasized that translating in the context of Bible "consists in reproducing in the receptor language the closest natural equivalent of the source language message, first in terms of meaning and secondly in terms of style" (Nida \& Taber, 1969: 12).

Catford (1965) adopted a linguisticbased approach to translation. He argued that defining the nature and conditions of translation equivalence is one of the main tasks of translation theory. In his view, translation is "the replacement of textual material in one language (source language SL) by equivalent textual material in another language (target language TL)" (Catford, 1965: 27). He differentiated between textual equivalence and formal correspondence. The former is "any TL text or portion of text which is observed on a particular occasion to be the equivalent of a given SL text or portion of text" (Catford, 1965: 27) and the latter is "any TL category (unit, class, structure, element of structure, etc. which can be said to occupy, as nearly as possible, the same 'place' in the "economy" of the TL as the given SL category occupies in the SL" (Catford, 1965: 27). An adverb, for example, should be translated by an adverb.

Halliday (2001) emphasized the significance of context and register variables in translation. He adopted 'a principle of hierarchy of values' the translators should follow:

Equivalence at different strata carries differential values; ... in most cases the value that is placed on it goes up the higher the stratum - semantic equivalence is valued more highly than lexicogrammatical, and contextual equivalence perhaps most highly of all; but ...these relative values can always be varied, and in any given instance of translation one can reassess them in the light of the task (Halliday, 2001: 17).

Baker (1992) suggested a more detailed distinction on the concept of equivalence at the following levels: equivalence that may occur at word level and above word level, equivalence at the grammatical level, Textual Equivalence and Pragmatic Equivalence. In this paper, we will mainly focus on grammatical equivalence 
that refers to the diversity of grammatical categories across languages. Baker (1992) noted that grammatical rules may vary across languages and this may pose some problems in terms of finding a direct correspondence in the target language. As a result, the translator might be forced either to add or to omit information in the target language (Baker, 1992: 82). Baker dealt particularly with five grammatical categories: number, gender, person, tense/aspect, and voice.

Exact equivalence is not always attainable because languages do not always use identical elements to express the same reality. STs need to know that the concept of equivalence "is usually intended in a relative sense - that of closest approximation to source text meaning" (Hatim \& Mason, 1990: 8). Translation is, therefore, not a process of mechanical substitution of source language words with similar words in the target language. Halliday (1967) put it clearly that translation is a process of three stages:

... (a) item for item equivalence; (b) reconsideration in the light of the linguistic environment and beyond this (it is almost an afterthought) to a consideration of the situation; (c) reconsideration in the light of the grammatical features of the target language where source language no longer provides any information (Newmark, 1991: 65).

Thus, translation is a communicative act which requires the use of "the common target patterns which are familiar to the target reader" for this use "plays an important role in keeping the communication channels open" (Baker, 1992: 57). Hence, instead of sticking literally to the text, translators can add, delete or change/shift forms to produce the communicative effect of the original text.

\section{Review of Literature}

There are relatively few empirical studies that dealt with the concept of grammatical equivalence or the translation of some morphological and syntactic constructions from Arabic into English and vice versa. Some of these studies will be summarized below:

Abdellah (2007) investigated the problems that encounter Arab students of English while translating Arabic endophora. The study concluded that students mistranslate the plural inanimate Arabic pronoun with the singular inanimate English pronoun. The study also showed that the error is more common in cases where the pronoun is cataphoric rather than anaphoric. In addition, the error was spotted more frequently in cases where the pronoun is distant from its antecedent.

Gadalla (2006) discussed the problems involving the translation of Arabic imperfect verbs. The study revealed the significance of understanding the contextual references of Arabic imperfect construction before translating them into English.

Bounaas (2009) investigated the errors made by university students in translating the accompaniment complement from Arabic into English. The findings revealed that the absence of the accompaniment complement equivalent in English and the students' misunderstanding of its meaning lead to inappropriate translations.

Al-Ghazalli (2013) investigated the translation of implicit negation from Arabic into English. By implicit negatives, the author means sentences that are semantically negated by the presence of some adverbials, quantifiers, conjunctions, particles, etc. The study concluded that the linguistic differences between Arabic and English have made the translation of such constructions difficult. 
Translators are sometimes forced to translate Arabic implicit negatives into English explicit negatives.

Abdelaal and Md Rashid (2016) dealt with grammar-related semantic losses in the translation of the Holy Qura'n, with special reference to Surah Al A'arāf (The Heights). The study showed that semantic losses occur in translating grammatical aspects such as conjunctions, syntactic order, duality, tense, and verbs.

Khafaji (1996) discussed the translation of passive voice from English into Arabic. The study concluded that only $25 \%$ of the passive verbs of the English source text (ST) were replaced by passive verbs in Arabic. Khafaji (1996) emphasized that Arabic is not a passive-avoiding language, but it utilizes various alternative avenues due to the rich morphological system of the Arabic verb and the relatively free word order of its sentences.

Khalil (1993) analyzed the problems involving the Arabic translations of English agentive passive sentences. A major problem encountered by Arab translators while translating such constructions has been the literal translation of the English by-agentive phrase into an Arabic equivalent by-agentive phrase. Such a rendition is not acceptable in standard Arabic and it is practiced under the influence of translation from European languages or due to the fact that such constructions are widely used in the Arab media.

Alqinai (2013) conducted a study on punctuations in Arabic and English and their translational implications. The study concluded that English punctuational marks are either deleted or substituted by Arabic lexical insertions in some cases. The study also concluded that the translation of such marks is likely to force the translator to realign meaning and reorder structure with a view to retaining the function of missing punctuation marks in the target text (TT).

Hence, the typological differences between Arabic and English make the achievement of plausible grammatical equivalence very challenging for STs as well as professional ones. Problems are likely to arise at different morphological and syntactic levels and they are not confined to the areas discussed in the afore-mentioned studies. The present study is therefore different from the above studies in that it attempts a taxonomy of those problems based on authentic texts that represent various genres and text typologies. In a sense, this study is an error analysis of STs' errors. However, instead of using traditional approaches and taxonomies such as Burt \& Kipersk, (1974), Corder (1967) and Richards (1971), it adopts a different approach to the identification and analysis of translation errors/problems based on Halliday's Systemic Functional Grammar (SFG). We agree with Halliday et al. (1964: 119) that error analysis is useful for the construction of a purely descriptive framework to look at the analysis and notation of errors. Halliday et al. (1964) recommended that after the collection of errors, the diagnosis of such errors can be done either descriptively or comparatively. The two methods are employed in this study. An SFG classification of translation errors/problems will transcend the limitations of traditional morphosyntactic error analysis. The use of semantic metafunctions in the analysis of translation errors/problems is likely to change the way teachers, editors and revisors of translation analyze and interpret errors.

\section{Theoretical Framework}

The taxonomy proposed in this study is based on a multifaceted conceptual framework 
drawing on insights from Halliday's SFG (Butt et al., 2000; Eggins, 2004; Halliday, 1994; Halliday \& Matthiessen, 2004; Martin \& Rose, 2003). SFG, according to Matthiessen (1995), views language as resource of several levels, namely, context, semantics, lexicogrammar, and phonology/graphology. The context level is an extra-linguistic level, and it includes both context of situation and context of culture. The context of situation refers to what is going on in the specific situation in which the text occurs and it can be analyzed through a register analysis of field, tenor, and mode. Field refers to what is being written about. Tenor refers to the social relationships involved in the text/speech. Mode refers to the form or channel of communication.

According to Halliday (1994: 35), a distinctive meaning is construed through three strands of meaning or metafunctions: ideational, interpersonal, and textual. The ideational metafunction is about the natural world and is concerned with clauses as representations. The interpersonal metafunction is concerned with clauses as exchanges. In other words, it deals with the social world, the relationship between text producer and text receiver. The textual metafunction, however, deals with the verbal world, and it is concerned with the clauses as messages. The metafunctions comprise the discourse semantics of a text and they are realized by the lexicogrammar. Besides, each metafunction is associated with one register variable (Eggins, 2004: 78) as follows:

- the field of a text is associated with ideational meaning, which is realized through transitivity patterns (verb types, active or passive structures, participants in the process, etc.);

- the tenor of a text corresponds to interpersonal meaning, which is realized through the patterns of modality (modal verbs and adverbs such as hopefully, should, possibly, and any evaluative lexis such as beautiful, dreadful);

- the mode of a text is associated with textual meaning, which is realized through the thematic and information structures (mainly the order and structuring of elements in a clause) and cohesion (the way the text hangs together lexically, including the use of pronouns, ellipsis, collocations, repetition, etc.) (Munday, 2001: 91).

In brief, each metafunction is realized through a particular system and those systems are associated with the situational aspects of register (Halliday, 1978, 1994). Kim (2007: 7) diagrammatically presents this correlation as in Figure 1.

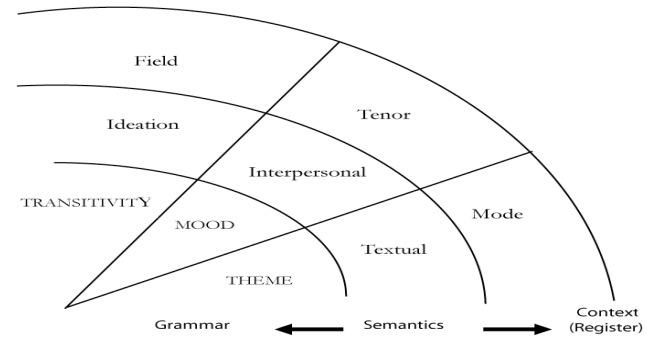

Figure 4.1 Grammar, Semantics and Context (Kim, 2007: 7)

In this study, we focus mainly on the lexico-grammatical stratum, which is defined by Matthiessen as follows:

Lexicogrammar: Resource for wording meanings, that is, for realizing (expressing) them by means of structures and 'words' (more strictly, grammatical and lexical items), or wordings. Lexicogrammar includes lexis (vocabulary) as well as grammar in one unified system; lexis is interpreted as the most specific (delicate) part of grammar. Grammar includes morphology as well as syntax; the two are not stratally distinct (Matthiessen, 1995:5). 
Syntactic structure in SFG is traditionally based around five grammatical units: sentence, clause, group, word, and morpheme. Those units are hierarchical in the sense that a textual sentence is likely to be made of a clause or a number of clauses, a clause complex. By the same token, a clause includes at least one phrase and more normally a (multivariate) phrase complex. Likewise, a phrase is likely to include smaller units such as a single (head) word or a word complex; and a word may comprise a morpheme or a morpheme complex (see Morley, 2000 for more details). As Droga and Humphrey (2003: 17) pointed out,

It is the larger 'chunks' of language (like clauses, word groups and phrases) that form meaningful message structures. These larger units are the grammatical structures used to package or organize the resources of the language system in a way that helps us achieve the various purposes for which we use language.

Therefore, a clause in SFG is the minimum meaning unit. Clauses are further divided into functional constituents for each metafunction. The ideational meaning can be realized through the transitivity system, which consists of three functional constituents: Participant, Process, and Circumstance. Interpersonal meanings can be realized through the mood system, which includes subject and finite relations. Likewise, theme-rheme and subordination-coordination relations are essential for the analysis of the textual function or thematic meaning (for detailed descriptions of these concepts see (Butt et al., 2000; Halliday, 1994; Halliday \& Matthiessen, 2004).

A fourth sub-function is suggested by Halliday and it is known as the logicosemantic metafunction. In our analysis, logico-semantic problems will be discussed under the textual metafunction because Halliday (1994) "includes conjunction - the explicit signaling of logico-semantic relations between clauses in the textual metafunction, which would mean that it should correlate with mode" (Ghadessy, 1999: 105).

Thus, SFG can enable us to identify the problems the STs experience at the various metafunctional levels as well as the stratification and rank vectors. The application of SFG gives more systematic interpretation "why one expression sounds natural and another does not. It is the assumption of SFG that it should be possible to find such explanations, even if they are not obvious or easy to formulate" (Kim, 2007: 30).

\section{Methodological Procedures}

This study used elicitation tasks as the main tool for collecting data. Seven short texts representing several text types/genres were selected from the translation materials used by instructors of the Department of English, Faculty of Arts, Taiz University. STs did the tasks in normal classroom conditions over a period of three months and they had access to different bilingual and monolingual dictionaries. The total number of STs who participated in the study is 25 . They have been in their final year of study. They were selected as subjects for this study based on their sound language skills. In addition, they have been studying English for ten years. At the time of conducting the elicitation tasks, the students had finished four obligatory modules (168 credit hours) in Arabic-English translation and vice-versa.

To allow them sufficient time to do the elicitation tasks, the selected texts were of suitable length to fit within the three-hour duration of the lecture. 
With reference to the students' academic performance of the previous year, we observed that they were academically on par. Based on this observation and the fact that group work is the most preferred method used by STs at Taiz University, we divided the students into five groups, five STs each. Group work was also employed in the study because it is based on the transformational approach to learning process, and it can be very beneficial to students. It is a learning-centred approach that focuses on collaborative learning and exploration of the translation process (Davies, 2004: 14)

Each group was asked to get their translations typed to facilitate the process of marking and compiling our parallel corpus. The translations of the STs were marked using Markin 4 software and a detailed feedback on each elicitation task was given to each group of STs on a weekly basis as is shown in Figure 2 below.

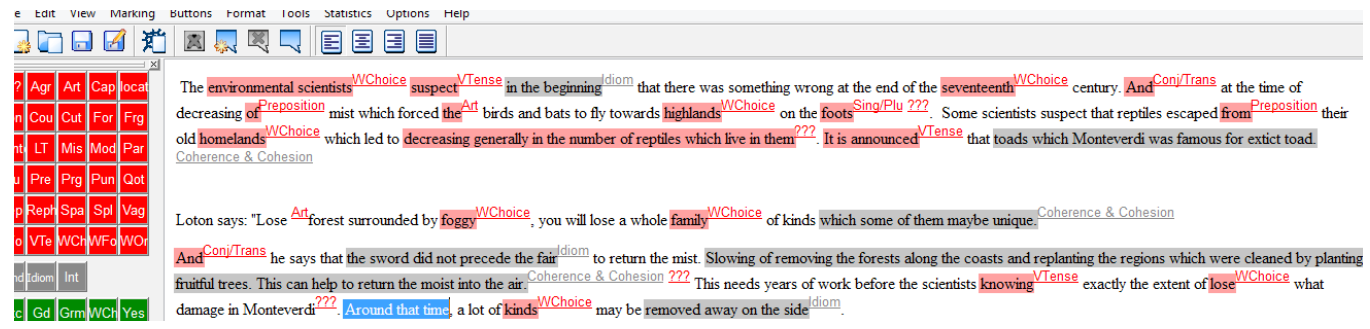

Figure 2. An example of a revised translation as marked in Markin 4.

All typed translations were collected from the STs and aligned with the source texts as is shown in Figure 3 below.

\begin{tabular}{|c|c|c|c|}
\hline Translation 3 & Translation 2 & Translation 1 & النص الأصلي \\
\hline $\begin{array}{l}\text { The environmentists doubt in the } \\
\text { beginning that there is a wrong thing } \\
\text { in the late seventies }\end{array}$ & $\begin{array}{l}\text { The environmental scientists suspect in } \\
\text { the beginning that there was something } \\
\text { wrong at the end of the seventeenth } \\
\text { century. }\end{array}$ & $\begin{array}{l}\text { The scientists of environment had doubts } \\
\text { in the beginning that there was a thing } \\
\text { that was not right in the end of the } \\
\text { seventies. }\end{array}$ & 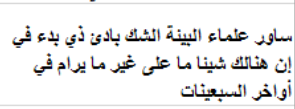 \\
\hline $\begin{array}{l}\text { They have observed a change in the } \\
\text { system of the wildlife in Monteverdi. }\end{array}$ & $\begin{array}{l}\text { when they observed a change in the } \\
\text { habits of wild life in Monteverdi. }\end{array}$ & $\begin{array}{l}\text { when they noticed change in habits of the } \\
\text { wild life in Montverde. }\end{array}$ & في مونت فردون الغير في عادات الحياة البرية \\
\hline $\begin{array}{l}\text { In the time when the mist or the fog } \\
\text { shrinks, the birds and bats were } \\
\text { forced to fly high }\end{array}$ & $\begin{array}{l}\text { And at the time of decreasing of mist } \\
\text { which forced the birds and bats to fly } \\
\text { towards highlands on the foots }\end{array}$ & $\begin{array}{l}\text { In the time in which the fog decreased, } \\
\text { the birds and the bats were forced to } \\
\text { flying towards higher places of highlands. }\end{array}$ & 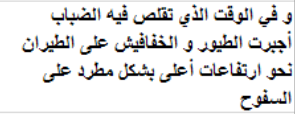 \\
\hline $\begin{array}{l}\text { Some scientists doubt that some } \\
\text { reptiles escaped of their homes. }\end{array}$ & $\begin{array}{l}\text { Some scientists suspect that reptiles } \\
\text { escaped from their old homelands. }\end{array}$ & $\begin{array}{l}\text { The scientists doubt that some reptiles } \\
\text { escaped from their old homes. }\end{array}$ & 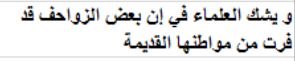 \\
\hline $\begin{array}{l}\text { As a result of this, the number of } \\
\text { reptiles decreased. }\end{array}$ & $\begin{array}{l}\text { which led to decreasing generally in the } \\
\text { number of reptiles which live in them. }\end{array}$ & $\begin{array}{l}\text { That leads to the general decrease in the } \\
\text { number of reptiles living in it. }\end{array}$ & القاطنة فئها ضلى ضمون عام في عدد الزبواحف \\
\hline $\begin{array}{l}\text { The toad was declared in } \\
\text { Monteverdi that was extinct. }\end{array}$ & $\begin{array}{l}\text { It is announced that toads which } \\
\text { Monteverdi was famous for extinct toad. }\end{array}$ & $\begin{array}{l}\text { The Ulgum that was found in Montverde } \\
\text { only was declared extinct. }\end{array}$ & 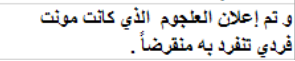 \\
\hline
\end{tabular}

Figure 3. A snapshot of the parallel corpus

Then, we used Quirkos, a computerassisted Qualitative Data Analysis Software (CAQDAS) for the coding and analysis of the corpus. The prefoliation of problems across different grammatical systems (i.e., transitivity, modality, theme-rheme) necessitates the use of a software to keep track on the categories in the translations of the five groups of STs. A mere alignment of the translations is hardly sufficient. Quirkos provides a graphical interface in which the nodes or themes of analysis (main problems in our context) are represented by bubbles as in Figure 4. 


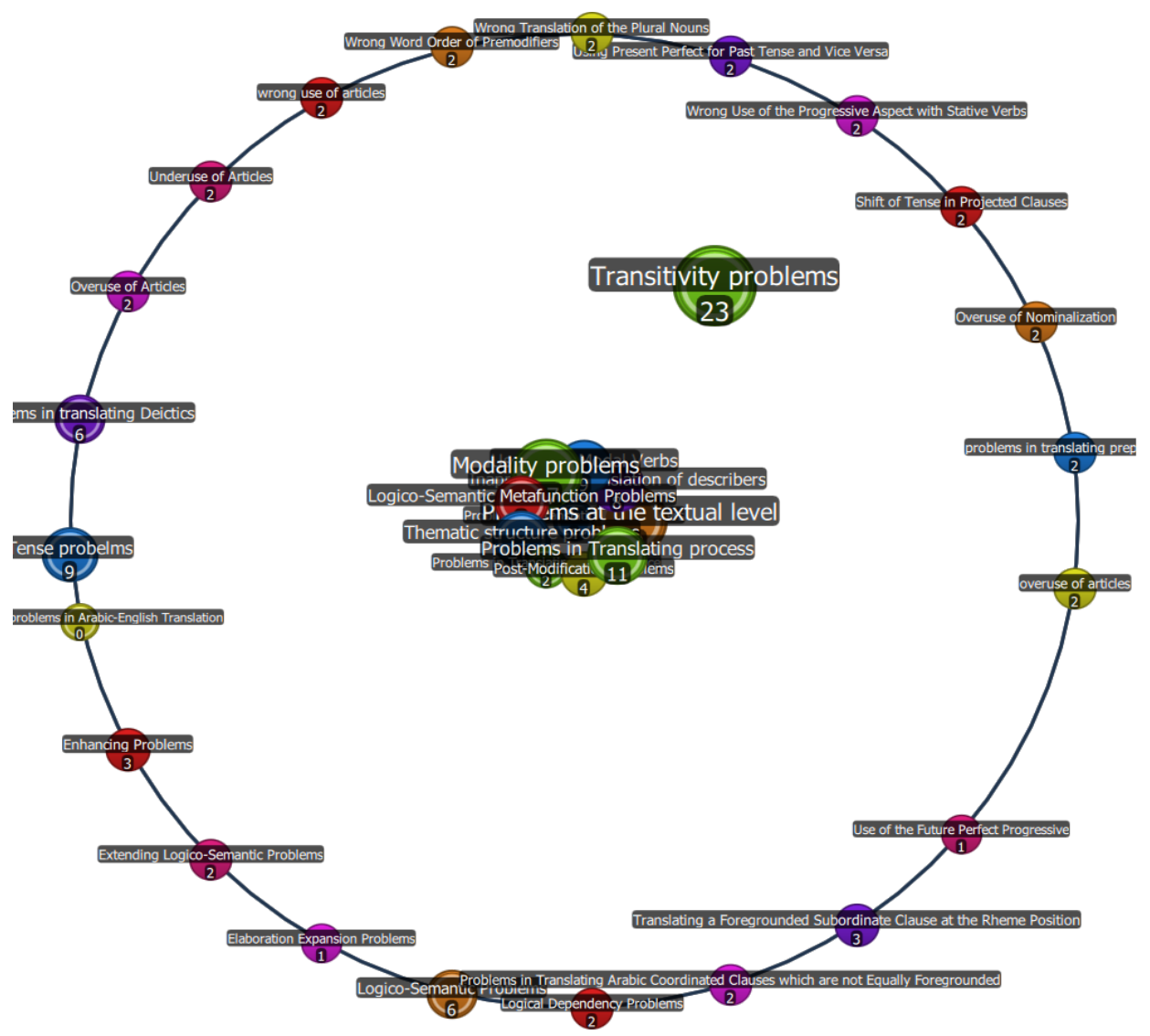

Figure 4. A Quirkos codifications of the translation problems in the parallel corpus

In our qualitative analysis of the examples given in the data analysis subsection in (6), we have followed the following procedures:

i - All problematic clauses and clauses complex were identified.

ii - Writing the source text in which a problem under investigation occurs and italicizing it.

iii - Transliterating the text.

iv - Giving the STs' translation(s) of the same text (i.e. the target text) with special focus on the problematic part under investigation.

$\mathrm{V}$ - Suggesting a more apt translation.

vi - Giving a critique on the STs' translation.
Therefore, the focus is on the grammatical problems in Arabic-English translation based on a corpus of authentic translated texts not from samples artificially composed.

\section{Data Analysis}

This subsection deals with the grammatical problems the STs encountered at the ideational, interpersonal, textual and logico-semantic metafunctions.

\subsection{Transitivity Problems}

According to Butt et al., (2000:52), the ideational metafunction of language is represented in grammar by clauses which consist of smaller experiential groups patterned to signify who did what to whom 
under what circumstances. The STs have experienced problems while translating some constituent functions of the experiential metafunction as shown below:

\subsubsection{Problems in Translating}

\section{Premodifications}

A clause is divided into a participant, a process, and a circumstance. The participant(s) in a process is (are) realized in the grammar by nominal groups. The structure of premodification in a nominal group can be reflected by one of four groups: deictics, numeratives, epithets, and classifiers.
Premodifications in a participant have posed some problems to the STs as follows:

\subsubsection{Problems in Translating Deictics}

Among the different categories of deictics, articles have posed several problems to the STs. Three types of problems recur:

\subsection{Overuse of Articles}

While translating the elicitation tasks, the STs have sometimes overused the articles, as shown in the following examples ${ }^{1}$ :

(1a) has been translated as (1b) but (1c) is more appropriate.

\begin{tabular}{|c|c|c|c|c|c|c|c|c|}
\hline (1a) & $f a$ & $f \grave{l}$ & l-waqt & taqallas & fihi & $l$-ḍabāb & ujbirat & l-tuyūr \\
\hline & And & in & the time & decreases & in it & the fog & forced & the birds \\
\hline
\end{tabular}

\begin{tabular}{|c|c|c|c|}
\hline wa & al-khafăfīsh & 'alā & 1-țayrān. \\
\hline and & the bats & on & the flying \\
\hline
\end{tabular}

\begin{tabular}{|c|c|}
\hline (1b) & At the time of decreasing the fog, the birds and the bats were forced to fly. \\
\hline (1c) & ...birds and bats have been forced to fly. \\
\hline
\end{tabular}

The use of the in (1b) is unwarranted about birds and bats. because the writer gives a general remark Another example is given in (2b).

\begin{tabular}{|c|c|c|c|c|c|c|c|}
\hline (2a) & tatahāwa & $l-k u t u b$ & $w a$ & $l-a t ̦ b \bar{a} q$ & $w a$ & $l-h u l l \bar{l}$ & min \\
\hline & fall & the books & and & the plates & and & the trinkets & from \\
\hline
\end{tabular}

\begin{tabular}{|c|c|}
\hline 'alā & 1-rufüf. \\
\hline on & the shelves \\
\hline
\end{tabular}

\begin{tabular}{|c|c|}
\hline$(2 \mathrm{~b})$ & The books, plates and jewelry on the shelves went up. \\
\hline$(2 \mathrm{c})$ & Books, plates, and knick-knacks.... \\
\hline
\end{tabular}

In this context, the writer does not refer to specific books, plates or knick-knacks and thus the use of the demonstrative deictic the is unwarranted.

\subsection{Underuse of Articles}

The STs have underused the articles in several instances. They have translated, for example, (3a) as (3b), while (3c) is more grammatically appropriate.

1. In each case (xa) is used to refer to the original text, (xb) to the STs' translation and (xc) and in a few instances $(\mathrm{xd})$ to the alternative translation(s) given by us. In each case, the original text is also followed by a literal translation. 


\begin{tabular}{|c|c|c|c|}
\hline$(3 \mathrm{a})$ & $\operatorname{la} h a z \bar{u}$ & taghyīr & $f i \ldots$ \\
\hline & noticed they & change & in \\
\hline (3b) & \multicolumn{3}{|c|}{ they notice change. } \\
\hline (3c) & \multicolumn{3}{|c|}{ they noticed $a$ change... } \\
\hline
\end{tabular}

The STs have incorrectly underused the indefinite article $a$ that functions as a non-specific pointer in (3b).

\subsection{Wrong Use of Articles}

Sometimes the STs have incorrectly used articles as reflected in (4b) and (5b) respectively.

\begin{tabular}{|c|c|c|c|c|c|c|}
\hline (4a) & $k a$ & wathīqah & $\min$ & wathäiq & majlis & al-amn. \\
\hline & as & a document & from & documents & council & the security \\
\hline$(4 b)$ & \multicolumn{6}{|c|}{... as a document of $a$ Security Council documents. } \\
\hline$(4 c)$ & \multicolumn{6}{|c|}{... as a document of the Security Council. } \\
\hline
\end{tabular}

The use of $a$ in (4b) is wrong. The text refers to the Security Council affiliated to the United Nations and thus the demonstrative deictic the should be used.

\begin{tabular}{|c|c|c|c|c|c|}
\hline$(5 a)$ & $A n$ & tafqid & ghäbah & yaksūhā & $l-d a b \bar{a} b, .$. \\
\hline & That & you lose & forest & covers it & the fog \\
\hline$(5 b)$ & \multicolumn{5}{|c|}{ Lose a forest surrounded by $a$ fog, $\ldots$} \\
\hline$(5 c)$ & \multicolumn{5}{|c|}{ Lose a forest covered with fog, ... } \\
\hline
\end{tabular}

In $(5 b)$, the STs have incorrectly used the indefinite article $a$ before the uncountable noun fog. Thus, the STs have experienced problems in rendering articles which may be attributed to the structural differences between Arabic and English. While English has two articles, Arabic has only one article, i.e., al which, like the, is used to express definiteness. Its absence, however, is a sign of indefiniteness. However, the cause for such problems may not be solely attributed to this factor. Tan (2004: 5) points out that people at large "de-emphasize the role of articles, thinking that it is immaterial to the meaning of a sentence $[\ldots]$ The fact, however, is that, under circumstances, the choices or use of an article will affect the meaning of a sentence".

\subsubsection{Wrong Word Order of Premodifiers}

Sometimes more than one premodifier can occur before the noun head. In such a case, the normal order can be deictic numerative epithet classifier (Butt et al., 2000: 53). This sequence of premodifiers can be problematic to STs as is clear from (6a) which has been translated by some STs as (6b).

\begin{tabular}{|c|c|c|c|}
\hline$(6 \mathrm{a})$ & $q u w w \bar{a} t$ & Amrīkiyyah & $k$ s̄șșah \\
\hline & forces & American & special \\
\hline$(6 \mathrm{~b})$ & \multicolumn{3}{|c|}{ American special forces. } \\
\hline$(6 \mathrm{c})$ & \multicolumn{3}{|c|}{ special American troops. } \\
\hline
\end{tabular}

In (6b), the classifier precedes the epithet, which is wrong. The problem is more serious when more than two modifiers appear in a clause. This problem may also be attributed to the fact that Arabic, unlike English, does not restrict the order of modifiers in a clause.
One of the problems that the STs have encountered while translating noun heads is that some nouns are either singular or plural in Arabic but only singular in English. The STs, for instance, have translated (7a) as (7b) but (7c) is more accurate.

\subsubsection{Wrong Translation of the Plural Nouns}




\begin{tabular}{|c|c|c|}
\hline (7a) & $\ldots a l-{ }^{c} a t \bar{a} d$ & $a l-h \bar{a} s \bar{u} b \bar{\imath}$ \\
\hline & the equipment (plural) & the computerized \\
\hline (7b) & \multicolumn{2}{|c|}{ computer equipments } \\
\hline (7c) & \multicolumn{2}{|c|}{ computer equipment } \\
\hline
\end{tabular}

The STs have rendered $a l^{-}$atâd, that is always plural in Arabic, as equipments, which is wrong. Equipment is an uncountable singular noun in English and thus it does not have a plural form.

\subsubsection{Process Problems}

Process is typically realized in English and Arabic grammar by verbal groups which "models the experience of eventness - whatever is happening, acting, doing, sensing, saying or simply being" (Butt et al., 2000: 55). The STs have experienced some problems while translating the process of a clause as follows:

\subsubsection{Tense Problem}

Processes can be regarded as "phenomena that unfold in time and hence have a tense system" (Matthiessen \& Halliday, 2009). The STs have faced several problems in the rendition of the tense systems as is clear from the examples below:

\subsection{Using Present Perfect for Past} Tense and Vice Versa

The translation of the present perfect can be very confusing. The STs, for instance, have translated (8a) as (8b), while (8c) is more appropriate.

\begin{tabular}{|c|c|c|c|c|c|c|c|}
\hline (8a) & 'āsha & qarāwiyyū & Sìnjādārah & wa & Ghurbāndāahah & bi- & Salām \\
\hline & lived & villagers & Singadarah & and & Gorbandarah & with & peace \\
\hline
\end{tabular}

\begin{tabular}{|c|c|c|c|c|c|c|}
\hline nisbī & 'alā & 1-jabal & al-ajrad & nafsih & wa & 1-wāqi \\
\hline relative & on & the mountain & the barren & itself & and & located \\
\hline
\end{tabular}

\begin{tabular}{|c|c|c|c|c|c|}
\hline shimāl & Kābūl & mundhu & zaman & ajdād & ajdādihim. \\
\hline North & Kabul & since & time & grandfathers & grandfathers their \\
\hline
\end{tabular}

(8b) Singadarah and Gorbandarah villagers lived peacefully on the barren mountain itself since the age of their forefathers.

(8c) The villagers of Sinjadarah and Gorbandarah have lived in relative peace... since the time of their great grandfathers.

What the writer wants to convey is that the residents of the two villages have lived in relative peace during the time of their forefathers and they have continued to live in harmony for years and perhaps for centuries. However, the use of the simple past in $(8 b)$ implies that the two villages lived peacefully in a specific time period which came to an end. Thus, it is more apt to use the present perfect in this context rather than the simple past tense.
6.1.2.1.2. Wrong Use of the Progressive Aspect with Stative Verbs

Some verbs are stative in that they describe a state or condition as opposed to material verbs which are dynamic. These verbs are rarely used in the present continuous. The STs, however, have sometimes used stative verbs in the progressive, as is clear from the following examples: 


\begin{tabular}{|c|c|c|c|c|c|c|c|}
\hline$(9 a)$ & $w a$ & $m \bar{a}$ & tadri & nafs & $m \bar{a} d h \bar{a}$ & taksib & ghadan \\
\hline & and & never & know & soul & what & earns & tomorrow \\
\hline$(9 \mathrm{~b})$ & \multicolumn{8}{|c|}{ No soul is knowing what will earn tomorrow... } \\
\hline (9c) & \multicolumn{8}{c|}{ No soul knows what it will earn tomorrow. } \\
\hline
\end{tabular}

In (9b), the STs have incorrectly used the verb know. Likewise, see is also a stative verb progressive aspect with the mental process which the STs have incorrectly used in (10b).

\begin{tabular}{|c|c|c|c|c|c|c|c|c|}
\hline (10a) & läkinnanī & arā & $f \grave{\imath}$ & Kull & 'ayn & min & 'uyūnikum & arā \\
\hline & but I & See & in & Every & eye & from & eyes your & I see \\
\hline
\end{tabular}

\begin{tabular}{|c|c|c|}
\hline 1-qawmiyyyah & al-'Arabiyyah & tanțaliq. \\
\hline the nationalism & the Arab & coming forth \\
\hline
\end{tabular}

\begin{tabular}{|c|c|}
\hline$(10 \mathrm{~b})$ & ...but I am seeing the Arab Nationalism shining of your eyes. \\
\hline$(10 \mathrm{c})$ & ...but I see Arab Nationalism in your eyes. \\
\hline
\end{tabular}

Here, the STs have incorrectly used the progressive aspect with the perception mental process verb see. The clause can be best rendered as (10c).

6.1.2.1.3. Useof the Future Perfect Progressive
Another problem the STs have experienced is the use of the future perfect progressive in English. (11a) has been translated by the STs as (11b), but (11c) is more accurate.

\begin{tabular}{|c|c|c|c|c|c|c|c|c|}
\hline$(11 \mathrm{a})$ & $W a$ & lākin & bi- & hulūl & dhālik & al-waqt & $f a$ & inna \\
\hline & and & but & by & the coming & that & the time & then & surely \\
\hline
\end{tabular}

\begin{tabular}{|c|c|c|c|c|c|c|c|}
\hline 1-' adīi & min & al-anwā' & yumkin & an takūn & qad & uzīhat & jāniban. \\
\hline the several & from & the species & perhaps & may be & indeed & put & aside \\
\hline
\end{tabular}

\begin{tabular}{|c|c|}
\hline$(11 \mathrm{~b})$ & ...but at that time many kinds may go aside. \\
\hline (11c) & ...but by that time, many species will/may have gone by the wayside. \\
\hline
\end{tabular}

Here, the text intends that some species will be extinct before ecologists even realize the extent of the great damage that has afflicted Monteverdi. Thus, the use of the future perfect as in (11c) is more apt in this context as it implies the completion of the action.

\subsection{Shift of Tense in Projected Clauses}

While reporting what someone else said or thought at a different time from the present, the STs have experienced difficulty in rendering the tense. The STs, for instance, have translated (12a) as (12b), but (12c) sounds more accurate.

\begin{tabular}{|c|c|c|c|c|c|c|c|}
\hline$(12 \mathrm{a})$ & $f a$ & $f \grave{l}$ & l-qaryah & al-mujāwirah & akhbaranā & 'ashrat & rijāl \\
\hline & and & in & the village & the nearby & told us & ten & men \\
\hline
\end{tabular}

\begin{tabular}{|c|c|c|c|c|c|}
\hline ākharīn & bi-annahum & jāhizūn & li- & 1-indimām & ilaynā. \\
\hline other & that they & ready & to & joining & us \\
\hline
\end{tabular}

\begin{tabular}{|c|c|}
\hline$(12 b)$ & In the next village, someone told us that ten other men are ready to join to us. \\
\hline$(12 \mathrm{c})$ & In a nearby village ten more men told us they were ready to join us. \\
\hline
\end{tabular}


Although there is no shift in mood choice between (12b) and (12c) as both are declarative, the tense choice undergoes a radical change. The tense choice should be made "in relation to the context of the report, not of the original speech events" (Thompson, 2004:210). It is, therefore, more appropriate to use the simple past rather than the present in the projected clause.

\subsubsection{Overuse of Nominalization}

Nominalization can be defined as the change of a process into a nominal. It is a transitivity feature that backgrounds "the process itself - its tense and modality are not indicated - and usually not specifying its participants, so that who is doing what to whom is left implicit" (Fairclough, 1993:179). Sometimes, the STs have inappropriately nominalized a clause where an event or happening can be appropriately packaged as a process rather than a participant, as is clear from the following examples:

(13a) has been translated as (13b) but $(13 c)$ is more suitable.

\begin{tabular}{|c|c|c|c|c|c|c|}
\hline (13a) & lākin & $m a^{c} a$ & Istimrār & $a l-q a s ̦ f$ & $a l-A m r \bar{k} k \bar{\imath}$ & Hunāk \\
\hline & but & with & continuation & the bombing & the American & There \\
\hline
\end{tabular}

\begin{tabular}{|c|c|c|c|c|c|}
\hline dalā'il & 'alā anna & l-da'm & al-sha' ${ }^{\prime} \bar{̄}$ & li-Ṭāliban & fì \\
\hline proofs & on that & the support & the people & to Taliban & in \\
\hline
\end{tabular}

\begin{tabular}{|c|c|c|c|c|c|c|}
\hline Ghurbāndārah & wa & Ghayrihā & 'alā & imtidād & Afghānistān & bi-lā shak \\
\hline Gorbandarah & and & others & on & along & Afghanistan & undoubtedly \\
\hline
\end{tabular}

\begin{tabular}{|c|c|c|}
\hline àkhidh & fì & 1-tabakhkhur. \\
\hline taking & in & the evaporating \\
\hline
\end{tabular}

\begin{tabular}{|l|l|}
\hline (13b) & $\begin{array}{l}\text { But with the continuation of the American bombing, there are indications that the folk support } \\
\text { to Taliban in Gorbandarah and in other villages along Afghanistan is becoming evaporation. }\end{array}$ \\
\hline (13c) & $\begin{array}{l}\text { But there are indications that as American bombing continues, grass-roots support } \\
\text { for the Taliban in Ghurbāndārah and similar villages throughout Afghanistan is } \\
\text { undoubtedly evaporating. }\end{array}$ \\
\hline
\end{tabular}

The excessive use of nominalization in (13b) is inappropriate in this context. It would be more appropriate to keep the process of the clause, instead of using the thing as an established fact. Although it is not wrong to use nominalization here, it weakens the clarity of the translated text.

\subsubsection{Post-Modification Problems}

A post-modification's function is to qualify the thing in more detail. It is functionally labeled as a qualifier and it gives more details about the thing by means of a clause or a prepositional phrase. A post-modification clause does not have an independent status as a clause because it functions as a qualifier within a group and it is called an embedded clause.

\subsubsection{Problems in Translating} Embedded Clauses

While translating post-modification from Arabic into English, the STs have faced certain problems in translating embedded clauses in general and defining relative clauses in particular' ${ }^{1}$. (14a), for example, has been translated as (14b) but (14c) is more accurate.

\footnotetext{
Not all relative clauses are embedded clauses. Examples of such clauses will be discussed later under the logico-semantic problems.
} 


\begin{tabular}{|c|c|c|c|c|c|c|c|}
\hline$(14 \mathrm{a})$ & $w a$ & yatazahzah & $a^{\prime} d \bar{a}^{\prime}$ & 'Abd al-Qayyūm & al-sābiqīn & li- tawfïr \\
\hline & and & budge & enemies & 'Abd al-Qayyūm & the former & to provide \\
\hline
\end{tabular}

\begin{tabular}{|c|c|c|c|c|c|c|}
\hline makān & al-șadārah & qurb & mișbāḥ & al-kīrūsīn & al-waḥīd & fī \\
\hline place & the central & near & lamp & the kerosene & the single & in \\
\hline
\end{tabular}

\begin{tabular}{|c|c|}
\hline wasaț & al-ghurfah. \\
\hline middle & the room \\
\hline
\end{tabular}

(14b) The former foes of Abdul-Qayoam moved to give him the best place which is near the only light in the middle of the room...

(14c) 'Abd al-Qayyūm's former enemies budge to give him pride of place by the single kerosene lamp in the middle of the room.

In (14b), the use of the prepositional embedded clause 'near...' sounds natural. However, the overuse of the relative clause 'which is ...' to qualify 'the pride of place' looks odd in this context.

\subsubsection{Problems in Translating}

\section{Circumstance}

The function of a circumstance in a clause is to illuminate the process in some way. It may locate the process in time or space or suggest how the process occurs (Butt et al.,
2000: 56). English, as well as Arabic, construct a model of circumstance in two ways: the adverbial groups and the prepositional phrase. In fact, prepositions, whether they occur in the circumstance or in the process (i.e., in phrasal verbs) can be very challenging for the translators. The STs have experienced problems in translating prepositions ${ }^{1}$ in the elicitation tasks. In some cases, they have underused and overused prepositions. In other cases, they have used the wrong prepositions. (15a), for example, has been translated as (15b), but (15c) is more accurate.

\begin{tabular}{|c|c|c|c|c|c|c|c|}
\hline$(15 a)$ & $f a$ & dakhala & $f i$ & l-nash & $w a$ & taghatțā & bi-l-shurās. \\
\hline & then & he entered & in & the coffin & and & covered himself & with the sheet \\
\hline$(15 b)$ & \multicolumn{7}{|c|}{ He entered in the coffin. } \\
\hline$(15 c)$ & & & ... & red the & $\mathrm{n} / \mathrm{go}$ & ato the coffin. & \\
\hline
\end{tabular}

In $(15 b)$, the preposition in has been overused. As opposed to (15a), in which the use of the preposition $f i$, the equivalent of in, can be used after the verb dakhala, 'entered' in (15b) does not need a preposition in this context. Enter into, however, can be used as a phrasal verb in the sense of 'taking part' or 'engage' (e.g. 'enter into a contract'), but not in the sense of 'having a shelter inside something'.
An example of the use of wrong preposition is given in (16b).

\footnotetext{
Prepositions, whether they occur in the circumstance or part of the process (i.e., in phrasal verbs), pose the same problems in Arabic-English translation.
} 


\begin{tabular}{|c|c|c|c|c|c|c|}
\hline$(16 a)$ & wa qad & itahama & $\sin \bar{a} t \bar{u} r$ & 'alā l-aqall & $\bar{U}$ riyu & bi-l-khiyānah. \\
\hline & And indeed & accused & senator & at least & $\bar{U}$ riy $\bar{u}$ & with the treason \\
\hline$(16 b)$ & \multicolumn{6}{|c|}{ At least one senator had accused Arui with disloyalty. } \\
\hline$(16 \mathrm{c})$ & \multicolumn{6}{|c|}{ One senator, at least, accused Orio of treason. } \\
\hline
\end{tabular}

The use of with after accused is wrong in (16b). Accused of is a more accurate and idiomatic phrasal verb.

\subsection{Modality problems}

Problems at the interpersonal metafunction are not as prevalent as ideational problems. The scarcity of interpersonal problems may be attributed to the nature of the texts under investigation. In fact, the texts under investigation mostly use declarative clauses with different types of processes but very few model finites. However, this does not mean that the texts are devoid of interpersonal roles or the translated texts have not included interpersonal problems. The STs have faced the following problems:

\subsubsection{Use of the Modal Verbs}

Halliday (1994) states that modality is a resource that sets up a semantic space between yes and no, a cline running between positive and negative poles (Martin \& Rose, 2003: 48). Sometimes the STs have translated the modal verb in such a way that the translation has led to a shift of interpersonal meaning. (17a), for example, has been translated as (17b), but (17c) preserves the interpersonal meaning better.

\begin{tabular}{|c|c|c|c|c|c|c|c|c|}
\hline$(17 \mathrm{a})$ & $W a$ & $y a q \bar{u} l$ & Lütūn, & "ikhsar & ghäbah & yaktanifuhà & al-dabāb & $f a$ \\
\hline & And & says & Loton & lose & forest & covered with & the fog & then \\
\hline
\end{tabular}

\begin{tabular}{|c|c|c|c|c|c|c|c|}
\hline takhsar & $' \bar{a} '$ ilah & kāmilah & min & al- anwā' & ba 'ḍhā & qad & yakūn \\
\hline lose & family & entire & from & the kinds & some & may & be \\
\hline
\end{tabular}

\begin{tabular}{|c|c|c|}
\hline farīd & min & naw 'ih.” \\
\hline rare & from & kind its \\
\hline
\end{tabular}

\begin{tabular}{|c|c|}
\hline$(17 b)$ & $\begin{array}{c}\text { Loton says, "losing a covered forest with fog, losing whole family from different } \\
\text { kinds, some of which is unique. }\end{array}$ \\
\hline$(17 \mathrm{c})$ & "Lose a cloud forest and you will lose a whole family of species, some of which may \\
be unique," says Loton.
\end{tabular}

The finite of the clause qad yakūn farìd min nawih calls for an indication of modality of probability or possibility, and it should be rendered as such in English. However, the STs have incorrectly translated it as a factual statement by using is as the finite of the clause in (17b). In other words, the modality of the original text that has been used to negotiate information (Martin \& Rose, 2003: 48) has been rendered as an assertive fact in (17b), while it should be rendered as an argument that allows an element of doubt. This shift of modality creates a wrong message in the target text.

Similarly, the STs have translated (18a) as (18b), but (18c) is more appropriate. 


\begin{tabular}{|c|c|c|c|c|c|c|c|}
\hline$(18 \mathrm{a})$ & ...inna & 'ad̄̄wāt & $a l-^{c} a q d$ & $a l-m \bar{a} d \underline{\imath}$ & yanbaghī & an tantahī & qarīban. \\
\hline & Surely & enmities & the decade & the last & must & end & soon \\
\hline$(18 b)$ & \multicolumn{7}{|c|}{ The hostility of the last decade should be ended soon. } \\
\hline$(18 c)$ & \multicolumn{7}{|c|}{..the enmities of the last decade must be ended soon. } \\
\hline
\end{tabular}

In (18a), yanbaghī implies certainty or logical necessity and compulsion. Thus, must is more appropriate in this context than should which, although it expresses an obligation, such obligation may not be fulfilled (Leech \& Svartvik, 1994: 164). In other words, arguing that 'something must be the case' is more assertive than 'something should be the case' because modality in the former occupies a higher position in the scale of positive polarity than the latter (Martin \& Rose, 2003: 49). For the speaker, all Afghans are obliged to reconcile and get rid of all the enmities of the last decade.

Another example is given in (19b).

\begin{tabular}{|c|c|c|c|c|c|c|}
\hline$(19 \mathrm{a})$ & $w a$ & $h \bar{a}$ dhihi & l-qābiliyyah & li - -la'allum & $\min$ & al-khibrāt \\
\hline & and & this & the capacity & for the learning & from & the experiences \\
\hline
\end{tabular}

\begin{tabular}{|c|c|c|c|c|c|c|}
\hline al-sābiqah & tuțịh & li- jamī' & al-ḥayawānāt & an tatakayyaf & ma'ā & 'ālam. \\
\hline the previous & enable & for all & the animals & to adapt & with & world \\
\hline
\end{tabular}

\begin{tabular}{|c|c|c|}
\hline mu'aqqad & wa & dā' ${ }^{\prime} \bar{m}$ al-taghyīr. \\
\hline complex & and & ever-changing \\
\hline
\end{tabular}

\begin{tabular}{|c|c|}
\hline (19b) & $\begin{array}{c}\text { This capability to learn from previous experiences may enable the animals to adapt } \\
\text { with changing and complex world. }\end{array}$ \\
\hline (19c) & $\begin{array}{c}\text { This aptitude to learn from previous experiences enables all animals to adapt to a } \\
\text { complex and ever-changing world. }\end{array}$ \\
\hline
\end{tabular}

While the Arabic clause expresses a factual statement, the STs have used the modal may which suggests possibility and uncertainty.

\subsubsection{Inappropriate translation of describers}

Appraisal emotional adjectives and adverbs have been sometimes inappropriately translated by the STs as we see in (20-22).

\begin{tabular}{|c|c|c|c|c|c|c|c|c|c|}
\hline$(20 a)$ & $A l-m \bar{a}{ }^{\prime}$ & sà'il & $l \bar{a}$ & laun & lahu & wa là & ța'm & wa lā & räiha \\
\hline & the water & liquid & no & colour & for it & and no & taste & and no & smell \\
\hline$(20 b)$ & \multicolumn{9}{|c|}{ Water is a liquid which does not have any color, or tastes or smell. } \\
\hline$(20 c)$ & \multicolumn{9}{|c|}{ Water is a colorless, tasteless and odorless liquid. } \\
\hline
\end{tabular}

In (20b), the STs have rendered the three describers as a relative clause that qualifies the word $s \bar{a}$ ' $i l$. The use of the three describers in (20c) seems more idiomatic in this context. Similarly, the expression wasat sakani in (21a), has been translated as a relative clause, even though the use of the expression habitual medium is a plausible equivalent describer to the Arabic expression.

\begin{tabular}{|c|c|c|c|c|c|c|c|}
\hline (21a) & $y a$ shaq & al-insān & al-taghyīr & wa lau & wajda & wasaț & sakan $\bar{\imath}$ \\
\hline & love & the man & the change & and if & find & medium & habitual \\
\hline
\end{tabular}




\begin{tabular}{|c|c|c|c|}
\hline 'la & dahr & al-marīkh & la-sakanah \\
\hline On & board & the Mars & lives in it \\
\hline
\end{tabular}

(21b) Man loves to change and if he finds a place in which he can stay on Mars, he will live (21c) Man loves change. Should he find a habitable medium on Mar, he would settle there.

Similarly, qarīr al-bāl in (22a) can also be better rendered as an adverb (i.e., peacefully) rather than a prepositional phrase (i.e., with a peace of mind).

\begin{tabular}{|l|c|c|c|c|c|c|c|}
\hline$(22 \mathrm{a})$ & Nām & al-rajl & qarìr & $a l-b \bar{a} l$ & $b a^{c} d a^{\prime} a n$ & $s \bar{a}^{c} d a$ & jarahu \\
\hline & slept & the man & peace & the mind & after & helped & his neighbor \\
\hline (22b) & \multicolumn{8}{c|}{ He slept with a peace of mind after he helped his poor neighbor. } \\
\hline (22c) & \multicolumn{6}{c|}{ Having helped his poor neighbor, the man had slept peacefully. } \\
\hline
\end{tabular}

\subsection{Thematic Structure Problems}

In so far as the thematic structure is concerned, the basic problems encountered by the STs are:

\subsubsection{Translating a Foregrounded} Subordinate Clause at the Rheme Position

One of the theme-rheme problems that the STs have faced is the translation of a foregrounded subordinate clause at the rheme position. Subordination in Arabic and English is a type of syntactic cohesion between clauses that do not bear equal status at both the syntactic and propositional levels. From a syntactic point of view, a subordinate clause is incapable of standing as a separate sentence and from a propositional perspective, it has a secondary informational content; it either modifies, amplifies, or forms part of the dominant proposition expressed by the main clause.

In both Arabic and English, subordinate clauses at the rheme position are usually expected to "convey information which is both backgrounded and relatively unpredictable" (Dickins et al., 2002: 122). But this is not always the case because a subordinate clause at the rheme position may convey information that is not only unpredictable but also foregrounded. The translation of such type of clauses has posed certain problems to the STs as is obvious from the following examples:

\begin{tabular}{|c|c|c|c|c|c|c|c|}
\hline (23a) & Inna & l-tarjamah & al-āliyyah & aw & $M T$ & kama & yurmaz \\
\hline & Surely & the translation & the machine & or & $M T$ & as & referred \\
\hline
\end{tabular}

\begin{tabular}{|c|c|c|c|c|c|c|c|}
\hline ilayhā & ahyānan & hiya & min & 'akthar & furū' & haql & al-dhakà' \\
\hline to it & sometimes & it is & from & the most & branches & filed & the intelligence \\
\hline
\end{tabular}

\begin{tabular}{|c|c|c|c|c|c|c|c|}
\hline al-iștinā $\overline{1} \overline{1}$ & takhallufan & idh & yakfī & wurūd & ism & 'alam & fì \\
\hline the artificial & underdeveloped & since & suffice & occurrence & noun & proper & In \\
\hline
\end{tabular}

\begin{tabular}{|c|c|c|c|c|c|c|}
\hline 1-nașṣ & 'aw & ba 'ḍ & ta 'bīrat & mușāgha & bi- 'ināyah & li-taḍlīl \\
\hline the text & or & some & expressions & crafted & with care & to mislead \\
\hline
\end{tabular}




\begin{tabular}{|c|c|c|c|}
\hline barāmij & al-tarjamah & bi-shakl & tāmm. \\
\hline programs & the translation & in shape & complete \\
\hline
\end{tabular}

\begin{tabular}{|c|c|}
\hline (23b) & $\begin{array}{c}\text { The automatic translation or MT, as indicated sometimes, is the most underdeveloped } \\
\text { branch of artificial intelligence field, when it is enough the mention a name in the text, } \\
\text { or some phrases formed carefully, to mislead the automatic translation programmes } \\
\text { totally. }\end{array}$ \\
\hline $\begin{array}{c}\text { (23c) } \\
\text { underdeveloped fields of artificial intelligence. A proper name or a few well-formed } \\
\text { phrases are sufficient to mislead the MT software completely. }\end{array}$ \\
\hline
\end{tabular}

Here, the subordinate clause at the rheme position (idh yakfi ...) is not only unpredictable but also foregrounded. It gives clear evidence of the failure of MT to cope with the capabilities of human translators. In (23b), the STs have inappropriately backgrounded the clause with when, which hardly makes sense in this context. It would be more appropriate if the subordinate clause at the rheme position is relayed as a separate clause in English as in (23c).

\subsubsection{Problems in Translating Arabic}

Coordinated Clauses which are not Equally Foregrounded

In fact, Arabic uses coordinating conjunction extensively in a text. The use of coordination implies that the propositions given by the relevant clauses are foregrounded and equal. However, it may happen that a coordination clause serves a propositionallybackgrounded function. This type of clauses could be problematic in translation. (24a), for example, has been translated as (24b) but (24c) is more acceptable.

\begin{tabular}{|c|c|c|c|c|c|c|c|c|}
\hline$(24 a)$ & $w a$ & istamarra & $n u z \bar{u} l$ & al-ghayth & $w a$ & $h \bar{a} d h \bar{a}$ & l-rajul & al-thānì \\
\hline & and & continued & fall & the rain & and & this & the man & the second \\
\hline
\end{tabular}

\begin{tabular}{|c|c|c|c|c|c|c|c|c|}
\hline yazuunn & annahu & waḥdahu & fĩ & zahr & al-sayyārah & wa & faj'atan & yukhrij \\
\hline thinks & that & alone & in & board & the car & and & suddenly & takes out \\
\hline
\end{tabular}

\begin{tabular}{|c|c|c|c|c|}
\hline hadhā & 1-rajul & yadahu & min & al-na'sh. \\
\hline this & the man & hand his & from & the coffin \\
\hline
\end{tabular}

\begin{tabular}{|c|c|}
\hline (24b) & $\begin{array}{c}\text { The rain continued to fall and the second man is thinking he is alone on the back of the } \\
\text { car, suddenly the man got his hand out to check whether it stopped or still raining... }\end{array}$ \\
\hline (24c) & $\begin{array}{c}\text { While it continued to rain, the second passenger thought he was alone in the truck and } \\
\text { all of a sudden the man in the coffin ..... }\end{array}$ \\
\hline
\end{tabular}

Although (wa istamarra nuzūl al-ghayth) and (wa hādha al-rajul...) are coordinated clauses, they are not equally foregrounded. In (24b), the STs have foregrounded the two clauses in their translations on the misconception that they hold equal status.
In this context, the fact that it continued to rain is well-known to the reader. Therefore, introducing the clause with the subordinating conjunction while as in (24c) looks more natural in English. 


\subsection{Logico-Semantic Metafunction Problems}

The STs have sometimes translated clauses in such a way that the logical metafunction between clauses is disturbed. That is, the relation between clauses is illogical. According to Halliday \& Matthiessen (2004: 373), two dimensions within clauses should be considered: logical dependency and logico-semantic relations. The former is concerned with whether a clause is dependent on or dominates another and the latter is concerned with the conjunctive relations between clauses. Problems at the logicosemantic metafunction can be categorized under two sub-headings:

\subsubsection{Logical Dependency Problems}

A common logical dependency problem encountered by the STs is the inappropriate use of parataxis. Parataxis and hypostasis is one of the pairs that "have come to play a major role in Halliday's later model of grammar- and especially in the framework that he uses for analyzing text-sentences in IFG" (Fawcett, 2000: 26). Parataxis simply means "putting" the clauses "side-by-side with no obvious cohesive links" (Fawcett, 1997: 96). The STs have sometimes unjustifiably underused cohesive devices. In other words, they tend to use parataxis where hypostasis is necessary. (25a), for instance, has been translated as (25b) whereas (25c) is more acceptable.

\begin{tabular}{|l|l|l|l|l|l|l|l|}
\hline (25a) & wa & $\min$ & al-zalām & yažhur & shakhș & bi-imāmah & wa \\
\hline & and & from & the darkness & appears & person & with turban & and \\
\hline
\end{tabular}

\begin{tabular}{|l|l|l|l|l|l|l|}
\hline ka-annahu & ta'kìd & 'alà & tanabbu'āt & B'̄gh. & Innahu & 'Abd alQayyūm \\
\hline as if & confirmation & about & predictions & Beigh & It is & 'Abd alQayyūm \\
\hline
\end{tabular}

\begin{tabular}{|c|c|c|c|c|c|c|}
\hline wa ahad & mawālìd & al-qaryah & wa & bi-șḥhbatih & zawjatah & wa \\
\hline and one & natives & the village & and & with his company & wife his & and \\
\hline
\end{tabular}

\begin{tabular}{|c|c|c|c|c|c|}
\hline Ibnahu & $d h \bar{u}$ & $a l$-sanawāt & al-arba'ah & li-l-indimām & li-taḥāluf \\
\hline son his & Of & the years & the four & for joining & for coalition \\
\hline
\end{tabular}

\begin{tabular}{|c|c|c|c|c|c|}
\hline al-shimāl. & $W a$ & yatazaḥzah & $a^{\prime} d \bar{a}$ & $'$ 'Abd al-Qayyūm & al-sābiqīn \\
\hline the north & and & move & foes & 'Abd al-Qayyüm & the former \\
\hline
\end{tabular}

\begin{tabular}{|c|c|c|c|c|c|c|}
\hline li-tawfïr & makān & al-șadārah & lahu & qurb & mișbāh & al-kirusīn \\
\hline for providing & place & the pride & for him & near & lamp & the kerosene \\
\hline
\end{tabular}

\begin{tabular}{|c|c|c|c|c|c|c|c|}
\hline al-wahìd & $f i$ & wasat & al-ghurfah & wa yajlib & Lahu & Khādim & al-shāy \\
\hline the single & In & middle & the room & and brought & to him & servant & the tea \\
\hline
\end{tabular}

\begin{tabular}{|c|c|c|c|}
\hline$w a$ & $l-k h u b z$ & $w a$ & $y a q u \bar{u} l \ldots$ \\
\hline and & the bread & and & says he \\
\hline
\end{tabular}




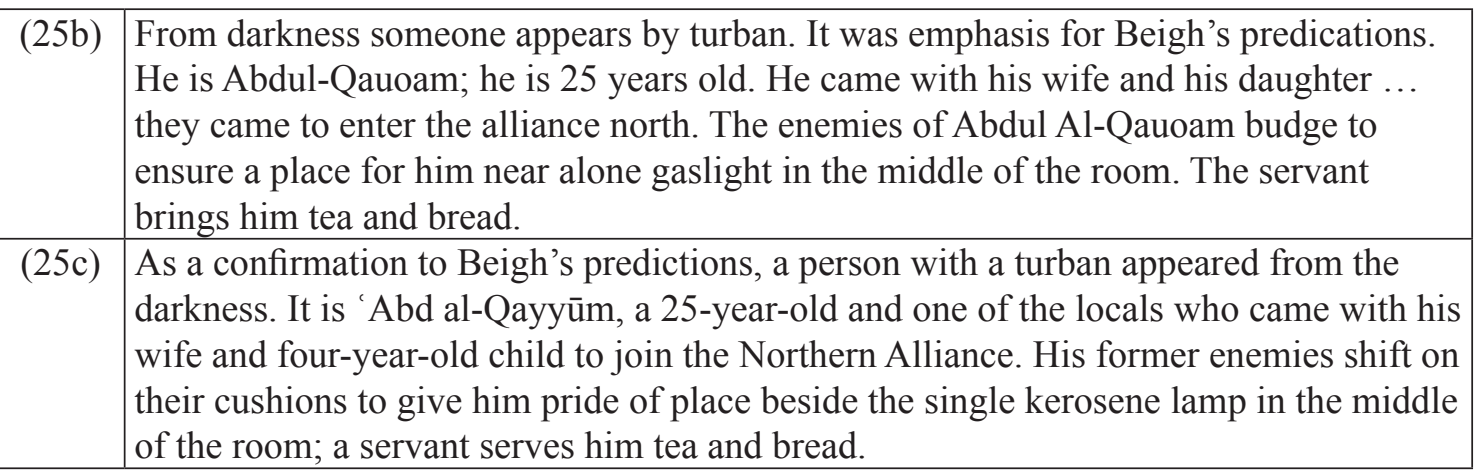

While (25a) includes eight connectives. The STs' version is almost devoid of any connectives. They have split the text and underused the connectives including 'and' throughout. This inappropriate use of parataxis disturbs the logical dependency relation between the clauses, and it gives the impression that all clauses are equal syntactically (i.e., all are dominant clauses) and informationally (i.e., all are foregrounded) while some clauses are dependent on others. An appropriate translation would read as (25c), where one hypotactic connective and three paratactic ones have been used.

\subsubsection{Logico-Semantic Problems}

Two basic logico-semantic relations exist between clauses: expansion and projection
(Halliday \& Matthiessen, 2004: 377). In case of expansion, one clause expands on the meaning of another in various ways. It may elaborate, extend, or enhance the other clause(s). In projection, on the other hand, "one clause projects another in the sense that it indicates that the other clause is a 'second-order' use of language; i.e., that, in the prototypical cases what is said in the projected clause has already been said somewhere else" (Thompson, 2004: 203). Examining the clauses in combination in the translations of the STs has highlighted the following problems:

\subsubsection{Elaboration Expansion Problems}

An example of this logico-semantic problem can be found in (26a), which has been translated by the STs as (26b) but (26c) is more accurate.

\begin{tabular}{|c|c|c|c|c|c|c|}
\hline (26a) & $w a$ & Tamma & $i^{`} \overline{l a ̄} n$ & al- $^{-}$uljūm & Bīfu Berīglenes & $w a-$ \\
\hline & and & completed & announcement & the toad & Beefo beriglenes & and \\
\hline
\end{tabular}

\begin{tabular}{|c|c|c|c|c|}
\hline kānat & Montverdī & tatafarrad & bi-hi & munqarị̣ \\
\hline was & Montverdi & unique & in it & Extinct \\
\hline
\end{tabular}

\begin{tabular}{|l|l|}
\hline (26b) & $\begin{array}{l}\text { And it was announced that the bright toad was extincting which Montverdi was } \\
\text { unique with. }\end{array}$ \\
\hline (26c) & $\begin{array}{l}\text { The golden toad (Bufo Periglenes), which was unique to Montverdi, has been } \\
\text { declared extinct. }\end{array}$ \\
\hline (26d) & $\begin{array}{l}\text { The golden toad (Bufo Periglenes) has been declared extinct; it was unique to } \\
\text { Montverdi. }\end{array}$ \\
\hline
\end{tabular}

In (26a), the expanding logico-semantic relation between clauses is one of elaboration. Although (kānat Montverdi tanfarid bi-hi) does not add any essentially new element to the message, it gives more information

\footnotetext{
4 The common problem in translating projection is the inappropriate use of the tense in the projected clause which has been discussed under the process problems in 6.1.2.
} 
about the golden toad. Although the STs have retained the relationship, they have used the hypotactic elaboration clause or the non-defining relative clause incorrectly. While the non-defining relative clause should immediately follow the participant (i.e., the golden toad) and thus it represents a kind of interpolation, suspending the dominant clause temporarily, the STs have translated it in such a way that the elaboration seems to refer to the whole of the preceding clause. It would be more acceptable had the STs maintained the elaboration relation as in (26c) or paratactically as in (26d).

\subsubsection{Extending Logico-Semantic}

Problems
Extending logico-semantic relations in Arabic clauses have caused some problems to the STs. The overuse of 'and', for example, has created several problems for them. This is partly because English and Arabic have different connective systems. Arabic, for example, tends to have long sentences connected by a basic connective such as wa, thumma and $f a$ or by a secondary connective like haythu. While translating such connectives, the STs have sometimes overused these connectives by translating them literally and thus the translations seem very exotic to the target reader as is clear from the following example:

\begin{tabular}{|c|c|c|c|c|c|c|c|}
\hline$(27 \mathrm{a})$ & $W a$ & $y a q \bar{u} l$ & inna & al-sayf & Lam & yasbiq & al- ${ }^{c}$ adhl \\
\hline & and & says he & surely & the sword & Not & precede & the blame \\
\hline
\end{tabular}

\begin{tabular}{|c|c|c|c|c|c|c|c|}
\hline li- & i'ādat & al-ḍabab & fa & ibțā' & izālat & al-ghābāt & 'alā imtidād \\
\hline to & restore & the fog & and & slowing & removing & the forests & along \\
\hline
\end{tabular}

\begin{tabular}{|c|c|c|c|c|c|}
\hline al-sawāhiil & wa & $\mathrm{i}^{\prime} \bar{a} d a t$ & zirā ${ }^{\prime}$ at & al-manāțiq & allatī \\
\hline the coasts & and & repeating & planting & the areas & which \\
\hline
\end{tabular}

\begin{tabular}{|c|c|c|c|c|c|}
\hline tamma & tanz̄īfuhā & bi- ashjār & muthmirah & yumkin & an yusā 'id \\
\hline completed & clearing them & with trees & fruitful & can & to help \\
\hline
\end{tabular}

\begin{tabular}{|c|c|c|c|c|c|c|c|}
\hline fì & i $\overline{\text { adat }}$ & al-rutūbah & ilā & 1-hawa ${ }^{\prime}$ & wa & sa-yatatallab & al-amr \\
\hline in & restoring & the moisture & to & the air & and & will require & the matter \\
\hline
\end{tabular}

\begin{tabular}{|c|c|c|c|c|c|c|}
\hline sanawāt & Min & al- 'amal & qabl an & ya 'lam & al' ulamà' $^{\prime}$ & bi l-ḍaț \\
\hline years & from & the work & before & know & the scientists & exactly \\
\hline
\end{tabular}

\begin{tabular}{|r|c|c|c|c|c|c|}
\hline madā & fadāḥat & mā & sayakūn & 'alayh & al-ḍarar & bi- Montverdi. \\
\hline extent & great & what & be & on it & the damage & on Montverdi \\
\hline
\end{tabular}

\begin{tabular}{|c|c|c|c|c|c|c|}
\hline wa lā-kin & bi- hulūl & dhālik & al-waqt & yumkin & an takūn & 1-'adīd \\
\hline but & the coming & that & the time & may & have been & several \\
\hline
\end{tabular}

\begin{tabular}{|c|c|c|c|c|}
\hline $\min$ & al-anwā & qad & uzīhat & jāniban. \\
\hline from & the species & indeed & brushed & aside \\
\hline
\end{tabular}


(27b) $\{$ And $\}$ he says the time is not over to get back the fog. The slowing of removing the forests along of beaches \{and\} the replacing the areas which had been cleaned with fruitful trees may help to return the humidity to the air. $\{$ And $\}$ this thing will require long years of work before the scientists know exactly the level of damage that caused in Montverdi but by that time a lot of kinds could go aside.

(27c) Time is not over, he says, to restore the clouds. Decreasing deforestation along the coastal areas \{and\} replanting cleared areas with fruit trees could help to restore moisture to the air. However, it will take years of work before scientists realize how severe the damage will be to Montverdi. By that time, several species may have gone by the wayside.

In so far as conjunctions are concerned, the STs have replaced each wa in Arabic with and in English which clashes with the English discourse and thus the translation seems exotic to the target reader. For the cohesion of the text, only the second and in (27b) should be retained.
An enhancing clause specifies an aspect of the dominant clause such as time, reason, condition, etc. In function, it can be similar to adjuncts. The STs have also faced some problems while translating clauses that enhance others. (28a), for example, has been translated as (28b) but (28c) is more accurate.

\subsubsection{Enhancing Problems}

\begin{tabular}{|c|c|c|c|c|c|c|}
\hline (28a) & Lam & tașilana & al-sila $^{c}$ & al-mațlübah & maca & annakum \\
\hline & did not & arrive us & the items & the ordered & although & you (pl.) \\
\hline
\end{tabular}

\begin{tabular}{|c|c|c|c|c|}
\hline afadtumūnā & bi-khițābikum & al-mu' arrakh [...] & bi-wusūl & țalabinā \\
\hline informed us & in letter your & dated & with arrival & order our \\
\hline
\end{tabular}

\begin{tabular}{|c|c|c|c|c|c|c|}
\hline raqam [...] & wa qad & awshaka & al-shahr & al-ḥālī & 'alā & l-intihā'. \\
\hline number & and indeed & about & the month & the present & to & end \\
\hline
\end{tabular}

\begin{tabular}{|c|c|}
\hline$(28 \mathrm{~b})$ & $\begin{array}{c}\text { The goods requested did not arrive yet, while you said in your letter dated ... that our } \\
\text { order was sent and this month is about to end. }\end{array}$ \\
\hline $\begin{array}{c}\text { (28c) } \\
\text { monthough our order no. } \mathrm{x} \text { was acknowledged in your letter dated ... and it is almost } \\
\text { monthets have not yet arrived. }\end{array}$ \\
\hline
\end{tabular}

In (28a), the first clause expands on the meaning of the second through enhancement. That is, the first clause adds specification concerning the concessive aspect of the dominant clause. Thus, this relation may be signaled by a conjunction such as 'although'. However, in (28b) the STs have used while that can function as a hypotactic extension, rather than a hypotactic enhancement conjunction.

\section{Conclusion and Possible Extensions}

It is clear from the analysis given above that the STs have experienced several stratification and rank problems and have used many words, phrases, and syntactic forms, which are either wrong or inappropriate. They have experienced problems while translating some constituent functions of the experiential metafunction. While translating the participants of a clause, one of the problems that were found is the translation of articles. Apart from the wrong use of articles, STs have sometimes overused and underused them. Arabic does not have any indefinite articles and it excessively uses the definite articles. 
The use of more than one modifier before a noun head in a clause can also be problematic. Arabic, unlike English, does not restrict the order of modifiers in a clause. In addition, number creates some problems for the STs in cases where a noun head is either a singular or plural in Arabic but it is only singular in English.

While translating the process of a clause, STs encountered several problems in translating tenses. That is attributed to the cross-linguistic variation in tense systems between Arabic and English. Although the Arabic perfect and imperfect tenses are remarkably parallel to the English past and present, the two languages differ significantly in terms of aspect. Verbs in English have two aspects: the perfect aspect and the progressive aspect. The present perfect which describes an action that started in the past and continued into the present is expressed in Arabic by the present tense. The preposition mundhu is used to specify at which point in the past the action started. This interprets why the STs sometimes wrongly translated the present perfect as a simple past. As far as the progressive aspect is concerned, the present is used in Arabic for both continuous and habitual actions and states.

Sometimes, the STs' inclination towards overgeneralization has led to some hypercorrection errors such as the use of the progressive aspect with stative verbs like 'knowing' and 'seeing'. The use of the progressive and perfect aspects such as future perfect progressive is even more problematic. Arabic uses the simple present in such cases as well. Futurity is expressed in Arabic by using some prefixes such as w or a particle such as saufa فوس. The STs have also encountered a problem in the rendition of tense in projected clauses. In addition, the STs have inappropriately nominalized a clause where an event or happening can be appropriately packaged as a process rather than a participant.

Another transitivity problem encountered by the STs is the translation of postmodification in a clause. A prepositional embedded clause has sometimes been translated as a relative clause especially in contexts where the prepositional clause can be part of a covert relative clause.

Prepositions in the circumstance of a clause also pose some problems to the STs. Although Arabic and English prepositions share some characteristics in common, they differ in both number and usage. Whereas there are only a few prepositions in Arabic, English has more than thirty prepositions. Besides, only a few Arabic propositions have exact equivalents in English. A preposition like $f_{\imath}$ can be translated as 'in', 'on', 'at', 'into', or 'inside'.

At the interpersonal metafunction, the STs encountered some problems in the rendition of modality. Sometimes the STs have translated the modal verb in such a way that the translation has led to a shift of interpersonal meaning. Such problems may occur because there are no modal auxiliaries in Arabic. Instead, Arabic uses some modal phrases and modelized expressions. In addition, the dynamics of power relationships are very different (Harris et al., 1997). Similarly, appraisal emotional adjectives and adverbs have been sometimes inappropriately translated by the STs.

At the textual level, the STs faced some problems in the translation of foregrounded subordinate clauses at the rheme position. Such clauses have been literally translated as subordinate clause even though the use of 
coordination clauses is more apt. By the same token, not all coordinated clauses are equally foregrounded, and they sometimes need to be translated as subordinate clauses.

In so far as the logico-semantic metafunction is concerned, the STs have sometimes translated clauses in combination (clause complexes) in such a way that the logical relation between clauses is disturbed. A common logical dependency problem encountered by the STs is the inappropriate use of parataxis. The STs have sometimes unjustifiably underused cohesive devices. In other words, they tend to use parataxis where hypostasis is necessary. STs are fully aware that Arabic tends to use coordinated connectives such as 'and' excessively and the literal translation of such connectives will make the translation very awkward. However, underusing connectives including 'and' is equally problematic.

The STs have also encountered certain problems in translating the expanding logicosemantic relation of elaboration as in the translation of non-defining clauses. Similarly, extending logico-semantic relations in Arabic clauses have caused some problems to the STs. Coordination through the use of connectives such as wa, thumma and $f a$ is more frequently employed than subordination in Arabic. The STs have sometimes overused these connectives by translating them literally and thus the translations seem very exotic to the target reader. The STs have also faced some problems while translating clauses that enhance others.

We may safely argue that most of the above problems are attributed to negative interference from Arabic. In most cases the STs' choice was guided by the structures of Arabic expressions. Had the STs paid equal attention to what is natural in such contexts in English, these incorrect or infelicitous expressions could have been easily avoided.

In short, it is not enough to identify whether there is a grammatical form or structure in the target language that is equivalent to that in the source language. It is also necessary to find out whether they are used in the same environment. If the formally equivalent expression of the target language is not used in that language the way it is used in the source language, the translator needs to establish what exactly can be used in its place. A translator should never undervalue the significance of those structural forms even if they do not lead to a shift in ideational metafunction. Structure does matter in translation. Its function, according to Berg (2009: 23), is "the gluing together of small units to form larger ones". It is parallel to "the concrete that is used to build houses from bricks" (Berg, 2009: 23).

It is worthwhile to mention that the taxonomy provided in this study is not exhaustive. It is based on a parallel corpus of translations of a number of texts. Larger and more coherent corpora will be needed to verify the taxonomy provided and to find out additional problems. A quantitative study examining the frequency of errors/problems among STs is also needed.

\section{Acknowledgements}

The author thanks the anonymous reviewers for their valuable comments and suggestions to improve the quality of the paper.

\section{References}

Abdelaal, N. M., \& Md Rashid, S. (2016). Grammar-related semantic losses in the translation of the Holy Quran, with special 
reference to Surah Al A'araf (The Heights). SAGE Open, 6(3), 1-11.

Abdellah, A. S. (2007). English Majors' Errors in Translating Arabic Endophora: Analysis and Remedy. Online Submission, CDELT (Centre for Developing English Language Teaching). Retrieved from https://eric. ed.gov/?id=ED536731

Alasmari, J., Watson, J., \& Atwell, E. S. (2016). A comparative analysis between Arabic and English of the verbal system using google translate. In Proceedings of IMAN'2016 4th International Conference on Islamic Applications in Computer Science and Technologies. Leeds.

Al-Ghazalli, M. F. (2013). Translation assessment of Arabic implicit negation into English. International Journal of English Linguistics, 3(2), 129-144.

Alqinai, J. (2013). Mediating punctuation in English Arabic translation. Linguistica Atlantica, 32(1), 2-20.

Baker, M. (1992). In Other Words: A Course on Translation. London and New York: Routledge.

Berg, T. (2009). Structure in Language: A Dynamic Perspective. New York and London: Routledge.

Bounaas, H. (2009). Difficulty in Translating the Arabic Grammatical Category The Accompaniment Complement into English (Unpublished MA thesis). Mentouri University, Constantine. Retrieved from https://bu.umc.edu.dz/theses/anglais/ BOU1107.pdf

Burt, M., \& Kipersk, C. (1974). Global and Local Mistakes, "in J. Schumann, N. Stenson (eds). New Frontier in Second language Learning. Rowley, Hass.: Newbury House.

Butt, D., Fahey, R., Feez, S., Spinks, S., \& Yallop, C. (2000). Using Functional
Grammar: An Explorer's Guide (2nd ed.). National Centre for English Language Teaching and Research: Macquarie University Sydney.

Catford, J. C. (1965). A linguistic Theory of Translation (Vol. 31). London: Oxford University Press.

Corder, S. P. (1967). The significance of learner's errors. IRAL-International Review of Applied Linguistics in Language Teaching, 5(1-4), 161-170.

Davies, M. G. (2004). Multiple Voices in the Translation Classroom: Activities, Tasks and Projects. Amsterdam/Philadelphia: John Benjamins Publishing.

Dickins, J., Hervey, S., \& Higgins, I. (2002). Thinking Arabic Translation: A Course in Translation Method: Arabic to English. London and New York: Routledge.

Droga, L., \& Humphrey, S. (2003). Grammar and Meaning: An introduction for Primary Teachers. Australia: New South Wales.

Eggins, S. (2004). Introduction to Systemic Functional Linguistics. London: Pinter Publisher.

Fairclough, N. (1993). Discourse and Social Change. Oxford: Wiley-Blackwell.

Fawcett, P. (1997). Translation and Language. Linguistic Theories Explained. Manchester: St. Jerome Publishing.

Fawcett, R. P. (2000). A theory of Syntax for Systemic Functional Linguistics (Vol. 206). Amsterdam: John Benjamins Publishing.

Gadalla, H. (2006). Arabic imperfect verbs in translation: a corpus study of English renderings. Meta: Journal Des Traducteurs/Meta: Translators' Journal, 51(1), 51-71.

Ghadessy, M. (Ed.). (1999). Text and Context in Functional Linguistics (Vol. 169). Amsterdam/Philadelphia: John Benjamins 
Publishing Company.

Halliday, M. A. K. (1978). Language as Social Semiotic. London: Arnold.

Halliday, M. A. K. (1994). An Introduction to Functional Grammar. London: Edward Arnold.

Halliday, M. A. K. (2001). Towards a theory of good translation. In E. Steiner \& Yallop (Eds.), Exploring translation and multilingual text production: Beyond content (Vol. 3, pp. 13-18). Berlin and New York: Walter de Gruyter.

Halliday, M. A. K., \& Matthiessen, C. M. (2004). Introduction to Functional Grammar. London: Edward Arnold.

Halliday, M. A. K., McIntosh, A., \& Strevens, P. (1964). The Linguistic Sciences and Language Teaching. London: Longmans.

Harris, C., McLaughlin, B., \& Still, M. (1997). Modals: a balancing act. Department of Applied Linguistics \& ESL, Georgia State University, Atlanta, Georgia, USA (Www2. Gsu. Edu/? Wwwesl/Issuel/Modaltoc. htm), 1-20.

Hatim, B., \& Mason, I. (1990). Discourse and the Translator. London: Longman.

Khafaji, R. (1996). Arabic translation alternatives for the passive in English. Papers and Studies in Linguistics. Retrieved from www.ifa.amu.edu.pl/psicl/ files/31/02Khafaji.pdf

Khalil, A. (1993). Arabic translation of English passive sentences: Problems and acceptability judgements. Papers and Studies in Contrastive Linguistics, 27(1), 169-181.

Kim, M. (2007). A Discourse-based Study on Theme in Korean and Textual Meaning in Translation ( $\mathrm{PhD}$ dissertation). Macquarie University, Sydney.

Leech, G., \& Svartvik, J. (1994). A
Communicative Grammar of English. London and New York: Longman.

Martin, J. R., \& Rose, D. (2003). Working with Discourse: Meaning beyond the Clause. London: Continuum.

Matthiessen, C., \& Halliday, M. A. K. (2009). Systemic functional grammar: a first step into the theory. Retrieved 24 November 2017, from https://www.researchgate. net/profile/Christian_Matthiessen/ publication/265398862_SYSTEMIC_ FUNCTIONAL_GRAMMAR_A FIRST_STEP_INTO_THE_THEORY/ links/54b513ef0cf28ebe92e4bacf/ S Y S T E M I C - F U N C T I O N A L GRAMMAR-A-FIRST-STEP-INTOTHE-THEORY.pdf

Matthiessen, C. M. I. M. (1995). Lexicogrammatical Cartography: English Systems. Tokyo: International Language Sciences Publishers.

Mohammed, T. A. S. (2011). A Taxonomy of Problems in Arabic-English Translation: A Systemic functional linguistic approach $(\mathrm{PhD}$ dissertation). University of the Western Cape, Cape Town.

Morley, G. D. (2000). Syntax in Functional Grammar: An Introduction to Lexicogrammar in Systemic Linguistics. London and New York: Contiuum.

Munday, J. (2001). Introducing Translation Studies: Theories and Applications. London: Routledge.

Newmark, P. (1991). About Translation. Clevedon/Philadelphia/ Adelaide: Multilingual Matters.

Nida, E. A. (1964). Toward a Science of Translating: With Special Reference to Principles and Procedures Involved in Bible Translating. Leiden: Brill Archive.

Nida, E. A., \& Taber, C. (1969). The Theory and Practice of Translation. Leiden: Brill. 
Richards, J. (1971). Error analysis and second language strategies. Language Sciences, $17,12-22$.

Shamsan, M. A.-H. A., \& Attayib, A. (2015). Inflectional morphology in Arabic and English: A contrastive study. International
Journal of English Linguistics, 5(2), 139-150.

Tan, C. (2004). Good English. Singapore: Singapore Asian Publications.

Thompson, G. (2004). Introducing Functional Grammar. London: Arnold.

\title{
NGHIÊN CƯU TƯƠNG ĐƯƠNG TƯ VỰNG - NGƯ' PHÁP TRONG DỊCH Ả RẬP - ANH
}

\author{
Tawffeek Abdou Saeed Mohammed Al-Kenani \\ Đại hoc Western Cape, Nam Phi \\ Robert Sobukwe, Bellville, Cape, 7535
}

Tóm tắt: Nghiên cứu này làm rõ khái niệm tương đương ngữ pháp trong dịch Ả Rập - Anh. Nghiên cứu tìm hiểu các vấn đề mà sinh viên học dịch gặp phải trong quá trình dịch các cấu trúc ngữ pháp từ tiếng Ả Rập sang tiếng Anh. Nghiên cứu dựa trên khối liệu là các bài dịch của năm nhóm sinh viên học dịch tại Bộ môn tiếng Anh, Khoa Nghệ thuật, Đại học Taiz, Yemen. Các nhóm sinh viên này đang học năm cuối khi làm các bài dịch sử dụng trong nghiên cứu này, và họ đã học bốn khoá dịch. Nghiên cứu kết luận rằng sự khác biệt về cấu trúc và hình thái giữa tiếng Ả Rập và tiếng Anh đã gây nhiều khó khăn cho sinh viên. Dựa theo ngữ pháp chức năng hệ thống (SFG), các vấn đề ngữ pháp liên quan đến siêu chức năng ý niệm, liên nhân, văn bản, và mối quan hệ logic-ngữ nghĩa được nhận diện. Ngoài ra, nghiên cứu kết luận rằng sinh viên gặp nhiều vấn đề về tính chuyển tác, tình thái, cấu trúc đề, sự phụ thuộc về logic, mối quan hệ logic-ngữ nghĩa giữa các cú. Các vấn đề này không chỉ ảnh hưởng đến khía cạnh ngữ pháp và phong cách của bản dịch, mà đôi khi còn tạo ra nét nghĩa khác với ý đồ của tác giả trong bản gốc.

Tù khoá: dịch, tương đương, ngữ pháp, tiếng Ả Rập, tiếng Anh, Ngữ pháp chức năng hệ thống,cú, sinh viên học dịch 